Jurnal Kependudukan Indonesia | Vol. 10 No. 2 Desember 2015 | 109-124

JURNAL KEPENDUDUKAN INDONESIA

p-ISSN : 1907-2902 (Print)

e-ISSN : 2502-8537 (Online)

\title{
MEMAHAMI ADAPTASI PENDUDUK TERHADAP PERUBAHAN IKLIM UNTUK PEMENUHAN KEBUTUHAN AIR BERSIH DI PULAU-PULAU KECIL BELITUNG DAN BINTAN
}

\author{
(UNDERSTANDING CLIMATE CHANGE ADAPTATION ON WATER \\ FULFILLMENT FOR SMALL ISLANDS POPULATION \\ IN BELITUNG AND BINTAN)
}

\author{
Laksmi Rachmawati \\ Pusat Penelitian Kependudukan, Lembaga Ilmu Pengetahuan Indonesia \\ Korespodensi Penulis: laksmi_rachma@yahoo.com
}

\begin{abstract}
Freshwater is an essential need for human being thus a sufficient supply of it it is required. Naturally, small islands are vulnerable. The occurence of climate change the vulnerability of these islands increase. Changes on temperature and precipitation can alter the hydrological cycle and will directly affect the water supply in small islands. This paper examines various adaptation efforts implemented by local population and government in small islands situated in Belitung and Bintan. Using quantitative method (survey to 400 respondents) and qualitative method (interview and focus group discussion), the research found that the adaptation has already taken place. The responsive/reactive and anticipatory adaptation are managed by government and local people who live in these small islands. Some of the adaptation actions are widening water storage, buying, searching for new water resources, desalination of salt water, rain water harvesting and improvement of water distribution. In addition, local mangrove management in Selat Nasik acts as adaptation functions for barriers of salt water intrusion. However, water governance has not been prioritized although it is proven to be necessary to support adaptive capacity for fresh water fulfillment
\end{abstract}

Keywords: Fresh Water Fulfillment, Small Islands, Adaptation, Responsive/Reactive, Anticipatory, Adaptive Capacity, Water Governance

\begin{abstract}
Abstrak
Pemenuhan kebutuhan air merupakan masalah pokok, mengingat air merupakan kebutuhan dasar manusia. Pulaupulau kecil merupakan wilayah yang secara alamiah rentan, dengan adanya perubahan iklim kerentanan pulau-pulau kecil akan meningkat. Perubahan temperatur dan pola curah hujan akibat perubahan iklim akan mempengaruhi siklus hidrologi yang pada akhirnya berdampak pada pasokan air bersih di pulau-pulau kecil. Tulisan ini bertujuan untuk mengkaji upaya adaptasi yang telah dilakukan oleh penduduk dan pemerintah di pulau-pulau kecil yang ada di Belitung dan Bintan. Penelitian dilakukan dengan mempergunakan metode kuantitatif (survei pada 400 responden) dan metode kualitatif (wawancara dan diskusi kelompok terfokus). Hasil studi di pulau-pulau kecil yang ada di Bintan dan Belitung menunjukkan telah ada upaya adaptasi yang bersifat responsif/reaktif dan antisipatif yang dilakukan oleh pemerintah maupun penduduk lokal. Beberapa upaya adaptasi yang telah dilakukan diantaranya dengan memperbesar tampungan sumber air, membeli, mencari sumber air baru, desalinisasi air, pemanenan air hujan maupun melakukan distribusi air yang lebih baik. Selain itu salah satu kegiatan menjaga ekosistem mangrove di Selat Nasik merupakan kegiatan adaptasi perubahan iklim yang dapat menjaga sumber air dari intrusi air laut. Namun demikian, pengelolaan air (water governance)belum menjadi prioritas padahal hal ini penting untuk meningkatkan kapasitas adaptasi penduduk terkait pemenuhan kebutuhan air bersih di pulau-pulau kecil.
\end{abstract}

Kata Kunci: Pemenuhan Kebutuhan Air Bersih, PulauPulau Kecil, Adaptasi, Responsif/Reaktif, Antisipatif, Kapasitas Adaptasi, Pengelolaan Air (Water Governance) 


\section{PENDAHULUAN}

Pemenuhan air bersih sebagai kebutuhan dasar manusia, merupakan salah satu masalah besar yang dihadapi oleh penduduk terutama mereka yang tinggal di pulau-pulau kecil. Secara alamiah, pulau-pulau kecil $^{1}$ memiliki banyak keterbatasan dalam ukuran, aksesibilitas, sumber daya yang terbatas dan kerentanan yang tinggi terhadap kejadian-kejadian bencana (Hess, 1990 ; Tompkins dkk, 2005). Studi yang dilakukan oleh Falkland (1992 dan 1993) telah menunjukkan bagaimana kondisi fisik dan geografi pulau kecil menjadi salah satu faktor yang harus diperhatikan terkait dengan pemenuhan kebutuhan air bersih penduduknya. Keterbatasan sumber daya secara langsung berpengaruh pada pasokan air bersih yang dapat dimanfaatkan oleh penduduk, namun kondisi fisik ini bukan merupakan satu-satunya faktor yang berpengaruh pada pemenuhan kebutuhan air bersih di pulau kecil. Pertumbuhan jumlah penduduk, pertumbuhan permintaan air, pengelolaan dan pemanfaatan air bersih serta pemahaman terhadap nilai-nilai budaya terkait air (Kuruppu, 2009) juga merupakan hal yang harus diperhatikan untuk dapat memenuhi kebutuhan air bersih penduduk di pulaupulau kecil.

Perubahan iklim menjadi satu fenomena signifikan yang tidak dapat dihindari karena terkait dengan meningkatnya risiko yang harus dihadapi terutama oleh penduduk di pulau-pulau kecil. Perubahan temperatur dan curah hujan akan merubah sistem hidrologi yang secara langsung berdampak pada stok air yang dapat dimanfaatkan (Bergkamp dkk, 2003). Selain itu, peningkatan risiko kejadian ekstrem juga akan terjadi dengan tingkat ketidakpastian yang tinggi (Adger dkk, 2003). Dalam laporan Intergovernmental Panel on Climate Change (IPCC) ke 5 (The Fifth Assessment Report) pada bagian pulau kecil, Nurse dkk (2014) memperlihatkan bagaimana peningkatan risiko dan kerentanan terjadi karena peningkatan frekuensi kejadian bencana hidrometeorologi yang akan berpengaruh signifikan pada (1) morfologi pulau, (2) ekosistem dan sumberdaya alam², (3) livelihood

${ }^{1}$ Dalam UU no 27 tahun 2007 dan UU no 1 tahun 2014, pulau kecil didefinisikan sebagai pulau dengan luas lebih kecil atau sama dengan $2.000 \mathrm{~km}^{2}$ beserta kesatuan ekosistemnya.

${ }^{2}$ Sumberdaya air masuk dalam bagian ini penduduk dan (4) perumahan dan infrastruktur. Selain karena perubahan temperatur dan curah hujan, risiko peningkatan intrusi air laut juga makin meningkat. Tidak hanya pulau-pulau atol ${ }^{3}$ yang secara ekstrem mengalami kesulitan air (White dkk, 2007), namun pulau-pulau kecil lain pun rentan terhadap kesulitan air bersih.

Studi-studi terkait pemenuhan kebutuhan air bersih di pulau-pulau kecil telah banyak dilakukan di Kepulauan Pasifik yang sejak awal tahun 90an mengkaji permasalahan kelangkaan air (water stress dan water scarcity) dan dampaknya ke penduduk (Falkland, 1992; Falkland, 1993; White dkk, 2004; White dkk, 2007; White dan Falkland, 2010). Lain halnya dengan Indonesia, dengan jumlah pulau kecil sekitar 17.500 pulau, belum banyak studi yang mengkaji secara khusus dampak perubahan iklim pada pemenuhan kebutuhan air bersih untuk pulau-pulau kecil di Indonesia. Studi terkait pemenuhan kebutuhan air bersih dan perubahan iklim di Indonesia masih sangat jarang sehingga artikel ini diharapkan mampu membuka mata bahwa secara sosial masalah pemenuhan kebutuhan air di pulau-pulau kecil di Indonesia telah terjadi dan perlu mendapat perhatian, terutama terkait bagaimana adaptasi perubahan iklim yang telah dan perlu dilakukan. Satu studi yang pernah dilakukan diantaranya di Spermonde, Sulawesi Selatan (Schwerdtner Manez ${ }^{4}$ dkk, 2012). Dalam studinya, Schwerdtner Manez dkk (2012) menunjukkan bahwa penduduk Spermonde telah mengalami kelangkaan air dikarenakan secara fisik kondisi pulau-pulau yang kebanyakan merupakan pulau atol memang sulit untuk menyimpan air sebagai cadangan groundwater. Selain itu perubahan curah hujan juga turut berperan mempengaruhi ketersediaan air tawar di pulau-pulau kecil di Spermonde. Di sebagian pulau yang diteliti oleh Schwerdtner Manez dkk (2012), adaptasi yang dilakukan adalah dengan membeli air dari Kota Makassaar, hal ini berarti ketergantungan penduduk pulau kecil pada daratan makin meningkat.

\footnotetext{
${ }^{3}$ Pulau atoll secara morfologi sulit untuk menyimpan air, sehingga relatif sumber air tanah menjadi sangat terbatas

${ }^{4}$ Studi di Spermonde dilakukan di Pulau Badi, Barrang Caddi, Bone Tambun dan Saugi
} 
Tulisan ini mencoba mengkaji bagaimana pemenuhan kebutuhan air bersih di pulau-pulau kecil, adaptasi ${ }^{5}$ yang telah dilakukan oleh penduduk maupun pemerintah untuk menghadapi kesulitan air karena dampak variabilitas dan perubahan iklim di Belitung (Provinsi Kepulauan Bangka Belitung) dan Bintan (Provinsi Kepulauan Riau). Artikel ini akan melihat pemenuhan kebutuhan air bersih tidak hanya dari aspek fisik saja, namun lebih menekankan pada kondisi sosial masyarakat berkaitan dengan pemenuhan kebutuhan air bersih. Hal ini berdasarkan pada argumen bahwa untuk memenuhi kebutuhan air bersih tidak hanya bergantung pada kondisi fisik sumber air namun lebih penting memahami perilaku penduduk maupun kelembagaan lokal untuk memenuhi kebutuhan pokok tersebut. Data yang digunakan bersumber dari bagian studi "Pengarusutamaan Adaptasi dalam Peningkatan Resiliensi Pulau-pulau Kecil”.6. Data yang dikumpulkan adalah data kuantitatif dan kualitatif di pulau-pulau kecil yang berada di Kabupaten Bintan (Provinsi Kepulauan Riau) dan Kabupaten Belitung (Provinsi Kepulauan Bangka Belitung). Pengumpulan data kuantitatif dilakukan dengan menggunakan kuesioner yang didistribusikan pada 200 rumah tangga di masing-masing lokasi ${ }^{7}$. Pengumpulan data secara kualitatif dilakukan dengan metode wawancara dan diskusi kelompok terfokus yang dilakukan pada masyarakat dan stakeholder pemerintah terkait.

\section{PENTINGNYA ADAPTASI TERHADAP PERUBAHAN IKLIM UNTUK MEMENUHI KEBUTUHAN AIR BERSIH}

Perubahan kondisi lingkungan baik karena perubahan iklim maupun karena faktor lain, maka menjadi sebuah keharusan untuk melakukan adaptasi terkait dengan upaya untuk memenuhi kebutuhan air bersih di pulaupulau kecil. Definisi tentang adaptasi perubahan iklim secara umum menjelaskan bahwa kegiatan adaptasi terhadap perubahan iklim adalah bagaimana individu atau kelompok mempertahankan tingkat kesejahteraan

\footnotetext{
${ }^{5}$ Adaptasi didalam artikel ini termasuk kegiatan yang bersifat response/ coping

${ }^{6}$ Studi ini merupakan salah satu kegiatan PN-9 Perubahan Iklim yang berada dibawah koordinasi Pusat Penelitian Geoteknologi LIPI (2014).

${ }^{7}$ Total kuesioner menjadi 400 buah untuk dua lokasi penelitian
}

penghidupan pada kondisi lingkungan yang berubah dengan melakukan dua hal yaitu mengurangi kerentanan atau dengan meningkatkan kapasitas adaptasi (IPCC, 2001; Gallopin, 2006). Untuk konteks Indonesia, Rencana Aksi Nasional Adaptasi Perubahan Iklim (RAN API) yang dikeluarkan oleh Bappenas pada Februari 2014 menyebutkan bahwa adaptasi merupakan upaya untuk meningkatkan ketahanan (resiliensi) suatu sistem terhadap dampak perubahan iklim $^{8}$. Untuk mewujudkan resiliensi diperlukan sinergi antara pusat dan daerah dalam merencanakan kegiatan adaptasi. Selain itu, pemahaman bahwa kegiatan adaptasi adalah hubungan timbal balik antara kondisi sosial dan kondisi ekologis menjadi syarat penting untuk tercapainya resiliensi.

Mengacu pada tipologi adaptasi yang dikembangkan oleh Smit dkk (1999) ${ }^{9}$ terdapat dua jenis kegiatan adaptasi yang dapat langsung terkait dengan adaptasi yaitu yang bersifat mandiri (autonomousresponsif/reaktif) dan yang direncanakan (planned antisipatif). Adaptasi mandiri karena bersifat otonom dan responsif dapat dilakukan baik oleh masyarakat maupun pemerintah sebagai respons atas kondisi yang dialami. Adaptasi mandiri sebenarnya dapat berlangsung tanpa dikaitkan dengan perubahan iklim, yaitu sepanjang ada usaha-usaha mengubah keadaan dan kebiasaan pengelolaan air menjadi lebih baik, seperti menghindari krisis air, kekeringan, dan banjir. Selain itu, sebagai sebuah respons, adaptasi mandiri tidak memerlukan adanya kajian kerentanan yang terkadang berisi kajian tentang proyeksi keadaan iklim dan kondisi stok air (KLH-GTZ-WWF, 2010) Lain halnya dengan adaptasi yang terencana dan bersifat antisipatif. Kegiatan adaptasi tipe ini biasanya akan memerlukan kajian kerentanan dan juga studi terkait skenario perubahan iklim sebagai dasar saintifik untuk menentukan opsi adapatasi yang diperlukan.

\footnotetext{
${ }^{8}$ Adaptasi perubahan iklim di Indonesia diarahkan sebagai: (1) Upaya penyesuaian dalam bentuk strategi, kebijakan, pengelolaan/manajemen, teknologi dan sikap agar dampak (negatif) perubahan iklim dapat dikurangi seminimal mungkin, dan bahkan jika memungkinkan dapat memanfaatkan dan memaksimalkan dampak positifnya.(2) Upaya mengurangi dampak (akibat) yang disebabkan oleh perubahan iklim, baik langsung maupun tidak langsung, baik kontinu maupun diskontinu dan permanen serta dampak menurut tingkatnya (RAN API, 2014 p.13)

${ }^{9}$ Tipologi adaptasi perubahan iklim dipaparkan berdasarkan atribut diantaranya tujuan, waktu dan jangkauan spasial, fungsi, bentukdan performance (Smit dkk, 1999)
} 
Tompkins dkk (2008) dengan mempertimbangkan tipologi adaptasi mengembangkan empat opsi pengelolaan kawasan pesisir yang dapat dikembangkan sebagai strategi dalam adaptasi perubahan iklim untuk wilayah pesisir. Dasar dari pembagian empat strategi ini lebih menitikberatkan pada proses pengambilan keputusan untuk kegiatan adaptasi yang dilakukan oleh pemerintah (bersifat top down) dan lokal/ masyarakat (bersifat bottom up); dan apakah kegiatan adaptasi tersebut terencana/antisipatif atau reaktif/responsif. Kombinasi keempat strategi tersebut dijelaskan dalam empat kuadran dalam gambar 1 berikut.

\section{Top Down/Tersentralisasi}

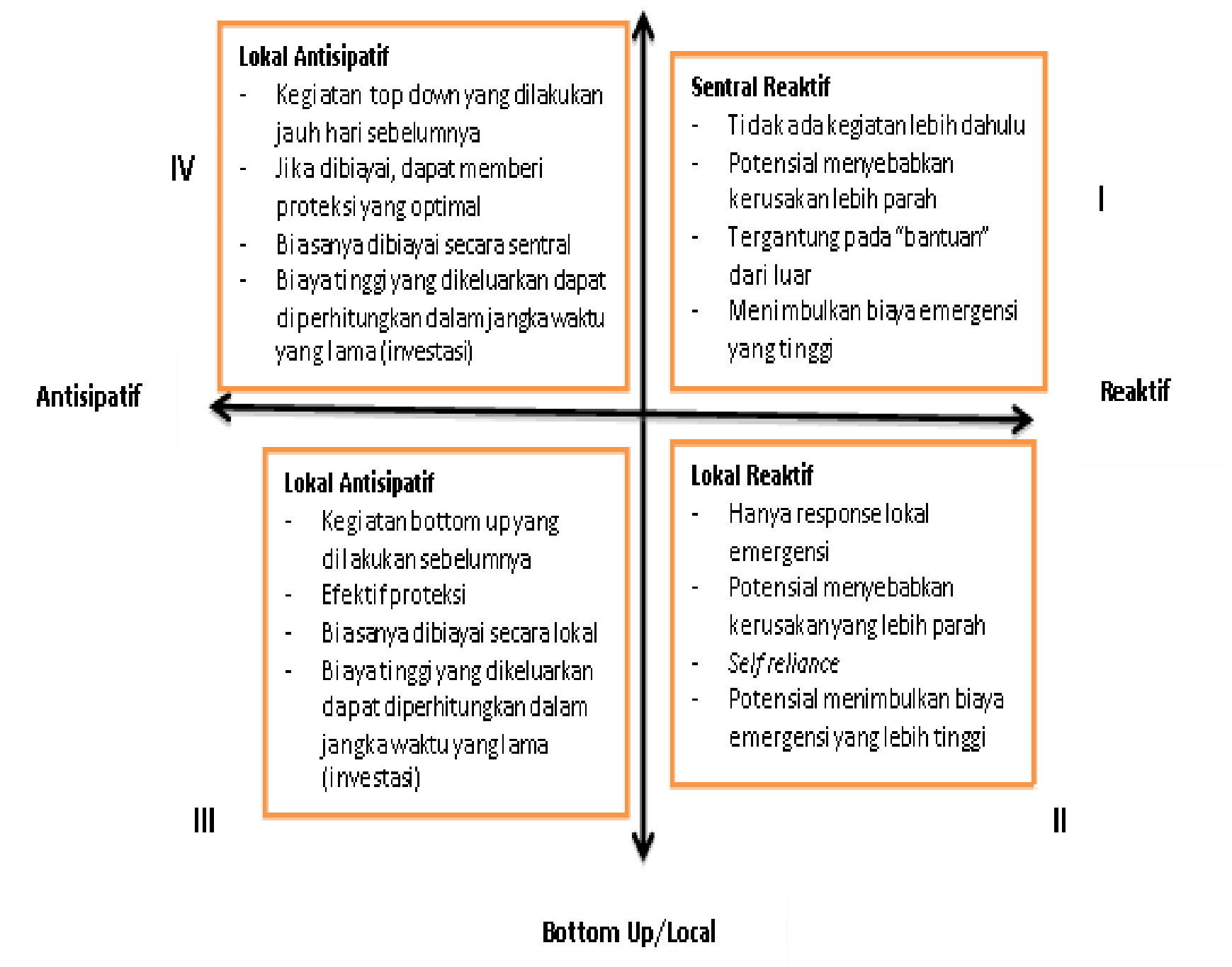

Gambar 1. Empat Opsi Pengelolaan Pesisir di Masa Mendatang sebagai bagian Strategi untuk Adaptasi Perubahan Iklim Sumber: Tompkins dkk (2008)

Strategi empat kuadran yang dikembangkan Tompkins dkk (2008) akan dipergunakan untuk memahami adaptasi yang sudah dilakukan terkait dengan pemenuhan kebutuhan air di pulau-pulau kecil yang ada di Belitung dan Bintan.

\section{DESKRIPSI DEMOGRAFI，KONDISI IKLIM DAN KERENTANAN DI BINTAN DAN BELITUNG}

Lokasi penelitian di Kabupaten Belitung terdiri dari empat desa yaitu tiga desa di Kecamatan Selat Nasik 
(Desa Suak Gual, Desa Petaling dan Desa Selat Nasik yang semuanya terletak di Pulau Mendanau) dan satu desa di Kecamatan Seliu (Desa Seliu).

Sedangkan untuk Kabupaten Bintan terdiri dari dua desa yang berada di dua kecamatan yaitu Desa Air
Glubi (Kecamatan Bintan Pesisir) dan Desa Mantang Lama (Kecamatan Mantang). Secara detil, informasi terkait kondisi demografi dan sumber air secara umum dapat dilihat pada tabel 1 berikut.

Tabel 1. Deskripsi Demografi, Kondisi Iklim dan Sumber Air di Bintan dan Belitung

\begin{tabular}{|c|c|c|c|c|c|c|c|}
\hline Kabupaten & Kecamatan & Desa & $\begin{array}{c}\text { Jumlah } \\
\text { Penduduk } \\
(2012)\end{array}$ & $\begin{array}{c}\text { Jumlah } \\
\text { KK }\end{array}$ & $\begin{array}{l}\text { Jumlah } \\
\text { Sampel }\end{array}$ & $\begin{array}{l}\text { Stasiun } \\
\text { cuaca } \\
\text { terdekat }\end{array}$ & Sumber air \\
\hline Bintan & $\begin{array}{c}\text { Bintan Pesisir } \\
\text { Mantang }\end{array}$ & $\begin{array}{c}\text { Air Glubi } \\
\text { Mantang } \\
\text { Lama }\end{array}$ & $\begin{array}{l}905 \\
848\end{array}$ & $\begin{array}{l}253 \\
\mathrm{Tt} *\end{array}$ & $\begin{array}{c}52 \\
148^{11}\end{array}$ & $\begin{array}{l}\text { Stasiun } \\
\text { Kijang- } \\
\text { Tanjung } \\
\text { Pinang }\end{array}$ & $\begin{array}{l}\text { Sumur sendiri, } \\
\text { Sumur bersama, } \\
\text { penampungan air } \\
\text { bersama/ kolam }\end{array}$ \\
\hline Belitung & Membalong & $\begin{array}{l}\text { Selat Nasik } \\
\text { Ptaling } \\
\text { Suak Gual } \\
\text { Pulau Seliu }\end{array}$ & $\begin{array}{c}2.467 \\
555 \\
871 \\
1.132\end{array}$ & $\begin{array}{l}779 \\
180 \\
257 \\
351\end{array}$ & $\begin{array}{l}90 \\
30 \\
40 \\
40\end{array}$ & $\begin{array}{l}\text { Stasiun } \\
\text { Tanjung } \\
\text { Pandan }^{12}\end{array}$ & $\begin{array}{c}\text { Sumur sendiri, sumur } \\
\text { bersama }\end{array}$ \\
\hline
\end{tabular}

Sumber: Kecamatan dalam Angka BPS Belitung dan Bintan beberapa penerbitan dan Hasil penelitian lapangan

*Tt : Tidak tersedia data

Berdasarkan kategori zona iklim, Kepulauan Riau termasuk dalam kategori zona iklim ekuatorial. Sedangkan untuk Kepulauan Bangka Belitung memiliki dua zona iklim yaitu zona ekuatorial untuk Pulau Belitung dan zona Monsunal untuk Kepulauan Bangka. Sesuai dengan zona musim ekuatorial relatif curah hujan cukup tinggi, namun baik Bintan maupun Belitung mengalami kejadian kekeringan pada musim- musim tertentu. Untuk Bintan, biasanya musim kering terjadi pada awal tahun, sekitar Bulan Januari-Maret. Sedangkan untuk Belitung, Bulan Agustus adalah bulan yang paling kering. Peta-peta berikut ini memperlihatkan bahwa berdasarkan BNPB, Kabupaten Belitung dan Kabupaten Bintan merupakan kabupaten yang memiliki risiko kekeringan yang tinggi.

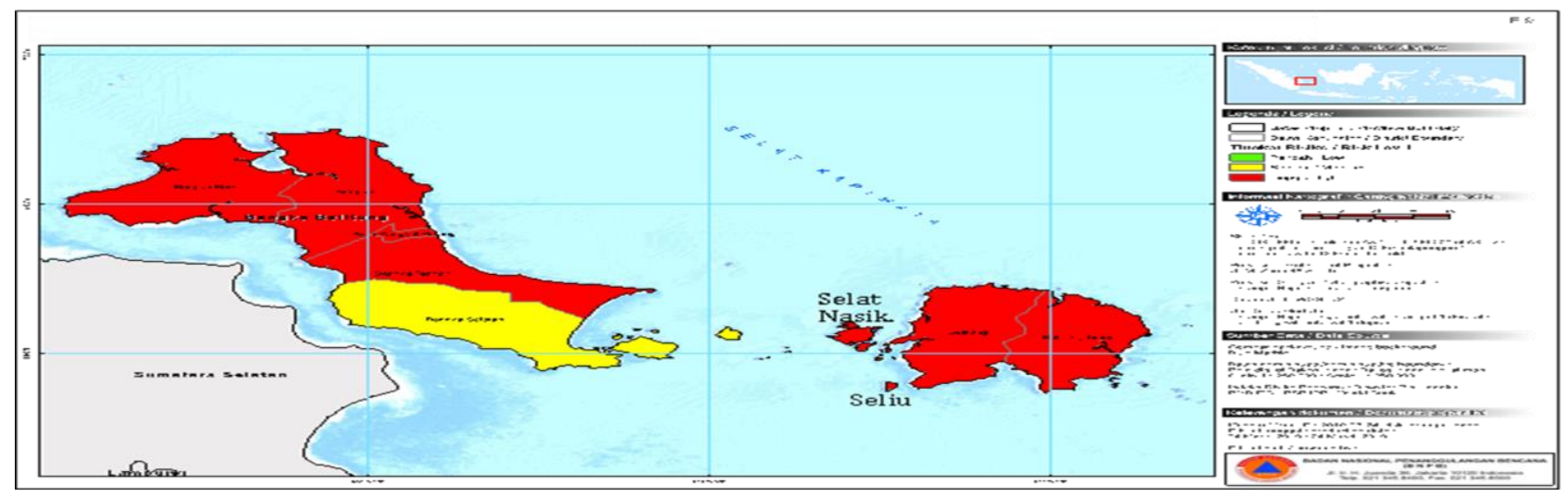

Sumber: Geospasial BNPB

Gambar 2. Peta Indeks Resiko Bencana Kekeringan di Provinsi Kepulauan Bangka Belitung

\footnotetext{
${ }^{10}$ Terdapat 6 stasiun cuaca di Kepulauan Riau yaitu Stasiun Hang Nadim Batam, Stasiun Kijang Tanjung Pinang, Stasiun Tarempa Anambas, Stasiun Ranai Natuna, Stasiun Dabo Singkep dan Stasiun Tanjung Balai Karimun.

${ }^{11}$ Jumlah responden di Desa Mantang jauh lebih banyak daripada di Desa Air Glubi karena Desa Mantang memiliki beberapa pulau-pulau kecil yang terpisah, sehingga penambahan sampel dilakukan untuk dapat mewakili beberapa lokasi terpisah tersebut.

${ }^{12}$ Terdapat dua stasiun cuaca yaitu Tanjung Pandang di Pulau Belitung dan stasiun Pangkal Pinang di Pulau Bangka
} 


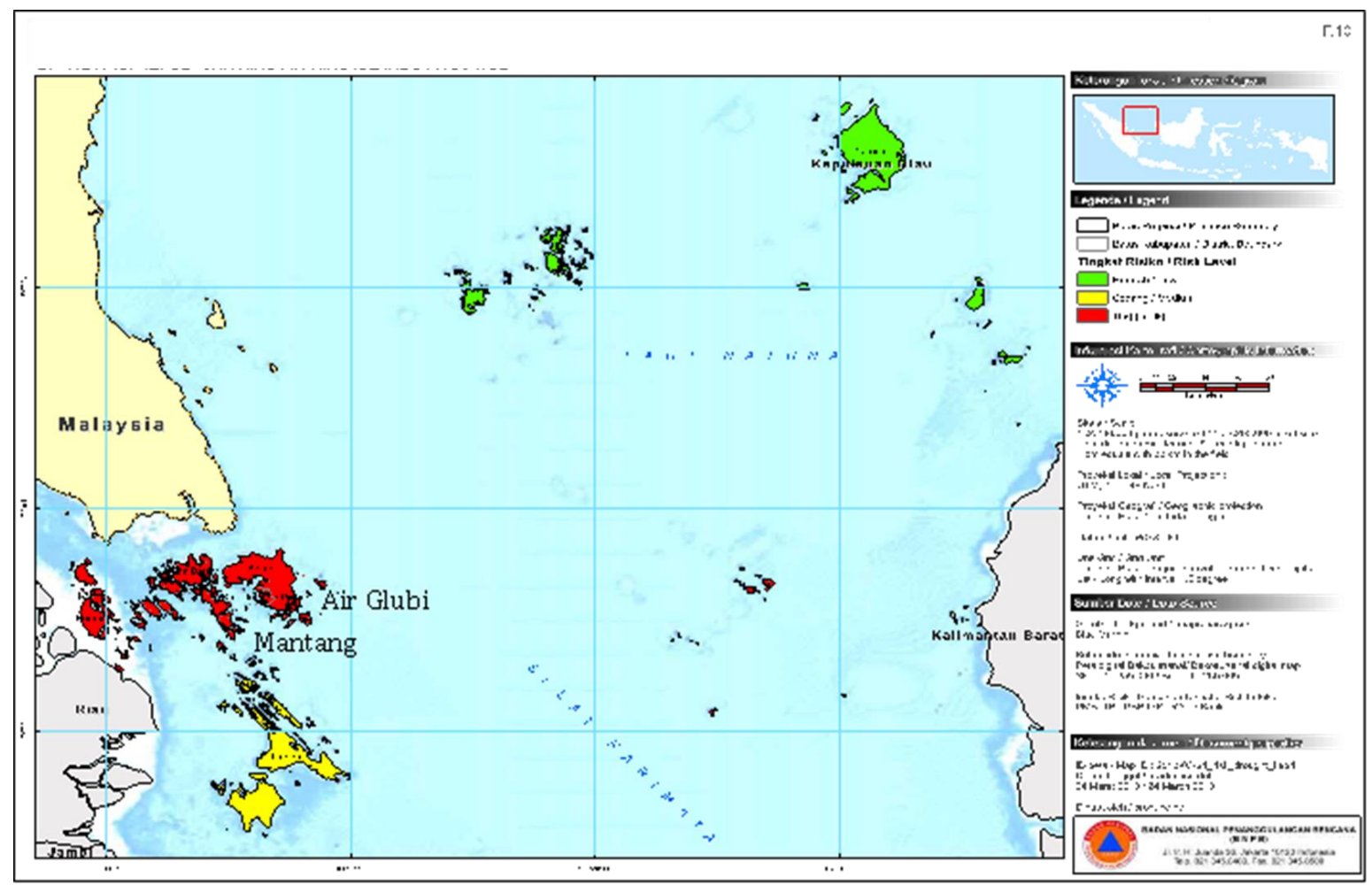

Sumber: Geospasial BNPB

Gambar 3.

Peta Indeks Resiko Bencaa Kekeringan di Provinsi Kepualauan Riau Sumber Pemenuhan Air Bersih di Pulau-Pulau Kecil di Bintan dan Belitung

Di Provinsi Kepulauan Riau dan Provinsi Bangka Belitung, secara umum penduduk yang tinggal di wilayah perkotaan mendapat akses untuk berlangganan air dari PDAM (PDAM Tirta Kepri-Tanjung Pinang dan PDAM Tanjung Pandan). PDAM Tanjung Pandan, memanfaatkan lahan eks tambang (kolong) ${ }^{10}$ sebagai sumber air baku untuk didistribusikan pada masyarakat. Sedangkan untuk PDAM Tanjung Pinang memanfaatkan air dari waduk ${ }^{11}$ untuk sumber air baku. Sumber-sumber air ini sangat tergantung pada curah hujan, sehingga perubahan curah hujan sangat mempengaruhi persediaan air. Persediaan air yang ada di sumber-sumber air tersebut secara normal tidak dapat mencukupi kebutuhan penduduk di Kota Tanjung Pandan dan Kota Tanjung Pinang. Menurut informasi dari masing-masing PDAM cakupan pelanggan baru mencapai 18 persen untuk PDAM Tanjung Pandan dan sekitar 40 persen untuk PDAM Tirta Kepri Tanjung Pinang. Bahkan, pada waktu

\footnotetext{
${ }^{10}$ Beberapa lokasi kolong diantaranya Air Serkuk dan Dukong

${ }^{11}$ Waduk yang sudah dipakai sejak lama adalah waduk Sungai Pulai. Sejak beberapa tahun terakhir sedang ditambah Waduk Sungai Gesek sebagai tambahan lokasi untuk menambahh daya tampung air baku PDAM Tirta Kepri.
}

curah hujan berkurang, terkadang sumber air yang ada menjadi kering sehingga pasokan untuk pelanggan PDAM menjadi terhenti. Terkadang PDAM harus menerapkan sistem giliran untuk pelanggannya ${ }^{12}$.

Selain memanfaatkan sambungan dari PDAM, banyak juga rumah tangga yang memakai air dari sumur (sumur sendiri maupun sumur bersama). Di Belitung, tidak semua sumur yang digali dapat menghasilkan air. Selain itu, sumur yang mengeluarkan air terkadang kualitasnya tidak seperti yang diharapkan karena tidak dapat dipergunakan sebagai sumber air minum karena kualitas air disebut sebagai aik teraja' atau air merah.

Karena keterbatasan sumber air, maka sumber air tersebut tetap dipergunakan oleh masyarakat. Untuk beberapa rumah tangga selain untuk keperluan MCK, terkadang air ini masih dikonsumsi untuk air minum. Namun untuk wilayah perkotaan kebanyakan rumah tangga membeli air galon untuk mencukupi kebutuhan air minum. Demikian pula untuk rumah tangga yang ada di Kota Tanjung Pinang, kualitas air sumur

\footnotetext{
${ }^{12}$ Pengelola PDAM Tanjung Pinang menyebutnya sebagai istilah "air jam-jam", karena bergilir dialirkan pada pelanggan.
} 
beragam dari yang putih bening sampai yang kekuning-kuningan, namun kuantitasnya tetap terbatas.

Pulau-pulau kecil lokasi penelitian tidak memiliki sambungan dari PDAM, sehingga untuk pulau-pulau yang ada di Bintan dan di Belitung sumber air penduduk untuk air minum dan MCK yang utama adalah sumur bersama seperti terlihat pada grafik 1 dan grafik 2 dibawah ini. Untuk pemenuhan kebutuhan MCK di Belitung, persentase terbesar adalah sumur bersama (60 persen). Selain itu untuk sumur sendiri sebesar 33 persen. Untuk 5 persen responden lainnya mengaku harus membayar untuk memenuhi kebutuhan $\mathrm{MCK}^{13}$. Kondisi yang hampir sama dapat ditemukan di Bintan, ditemukan 50 persen penduduk menggunakan sumur bersama. Namun 24 persen

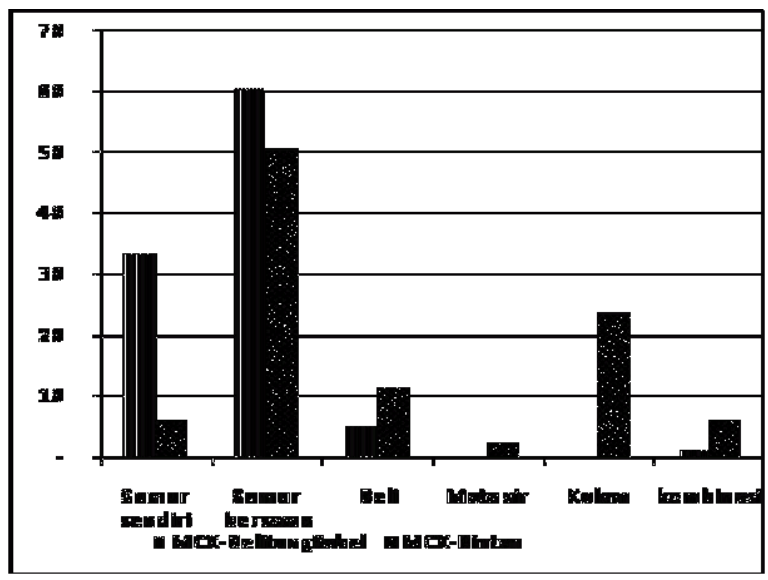

Grafik 1

Sumber air untuk MCK di Lokasi Penelitian $(n=400)$ persen untuk Bintan dan 17,5 persen untuk Belitung) membeli bukan menjadi sumber dominan untuk pemenuhan kebutuhan air.

Sumber air yang bersifat komunal merupakan sumber air utama. Hal ini disebabkan oleh kondisi geografis pulau yang tidak memungkinkan masing-masing rumah tangga untuk memiliki sumur sendiri-sendiri. Terkadang rumah tangga yang berusaha untuk menggali sumur tidak mendapatkan air. Untuk kasus Belitung, beberapa rumah tangga mencoba menggali sumur dan mendapatkan air teraja' sehingga akhirnya tetap memakai sumur bersama karena kualitas air yang lebih baik. Contoh lain di Desa Suak Gual (Kecamatan Selat Nasik, Belitung) masih terdapat sebuah sumur tua yang dimanfaatkan oleh warga untuk minum

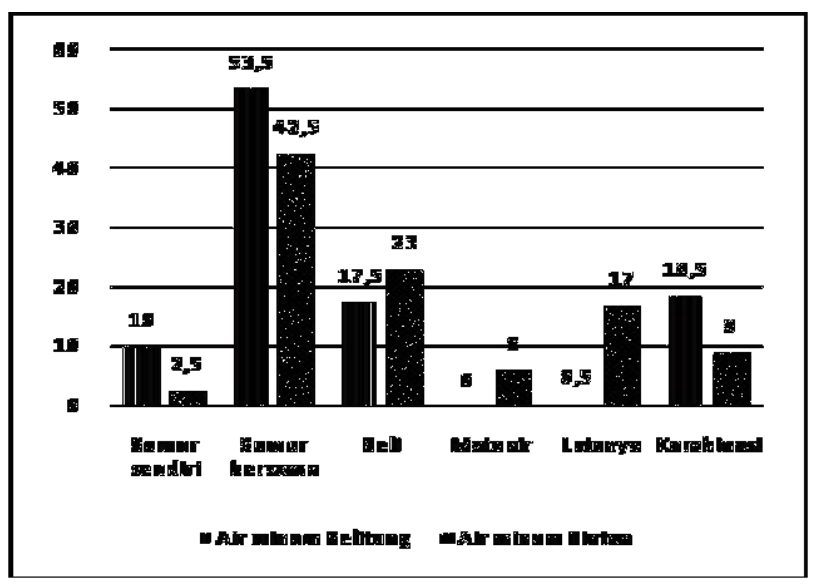

Grafik 2 .

Sumber air untuk minum di okasi Penelitian

Sumber: Survei Pengarusutamaan Adaptasi dalam Peningkatan Resiliensi Pulau-pulau Kecil, Kerjasama PPK LIPI dan Geotek LIPI 2014

responden di Bintan, mengaku juga memanfaatkan air kolam. Kolam ini merupakan kolam eks tambang yang dimanfaatkan untuk tampungan air. Pola konsumsi masyarakat akan air, tidak berubah secara drastis seperti di wilayah Spermonde yang merupakan kawasan atol. Hasil temuan Schwerdtner Manez dkk (2012) menyebutkan di wilayah yang diteliti di Spermonde telah ditemukan perubahan pola konsumsi air dari pemanfaatan sumur menjadi membeli air dari Makassar. Sedangkan untuk Belitung dan Bintan, hasil survei menunjukkan bahwa walau relatif signifikan (23

\footnotetext{
${ }^{13}$ Membayar dalam artian mengupah orang untuk mengangkut air atau membeli air jerigen
}

maupun untuk MCK. Walau sekarang yang mengambil air di sumur tersebut tidak sebanyak dulu, karena sudah dibangunnya beberapa sumur baru disekitarnya, namun tetap saja banyak warga yang memanfaatkan sumur ini.

\section{DAMPAK PERUBAHAN IKLIM TERHADAP PEMENUHAN KEBUTUHAN AIR BERSIH DI BINTAN DAN BELITUNG}

Kondisi yang hampir sama dengan yang terjadi di Spermonde juga terjadi di pulau-pulau kecil di Provinsi Kepulauan Riau maupun di Provinsi Kepulauan Bangka Belitung, dengan tingkat keparahan yang berbeda. Sebagai bagian dari kepulauan yang ada 
di Indonesia, secara spesifik di beberapa wilayah kepulauan memiliki curah hujan sebenarnya cukup tinggi, hujan relatif dapat ditemui sepanjang tahun namun antara musim hujan dan musim kemarau tidak dapat dipisahkan secara jelas seperti ikim yang terjadi di daratan. Hujan bisa saja datang setiap seminggu atau dua minggu sekali, sehingga sumur akan kembali terisi oleh air hujan. Kondisi pola hujan seperti ini yang membuat ketersediaan air di pulau-pulau kecil ini dapat dipastikan selalu tercukupi, dimana semua penduduk yang tinggal tergantung pada kondisi ini.

Bila kondisi normal, relatif persediaan air dapat mencukupi untuk kebutuhan sepanjang tahun. Namun kejadian kekeringan sebagai salah satu indikator kejadian variabilitas dan perubahan iklim telah dapat ditemui di Provinsi Kepulauan Riau dan Bangka Belitung. Di Kepulauan Riau, kejadian ekstrem kekeringan terjadi pada awal tahun 2014 di Kepri. Pada saat itu hujan tidak turun selama 45 hari (pertengahan Bulan Januari sampai akhir Februari

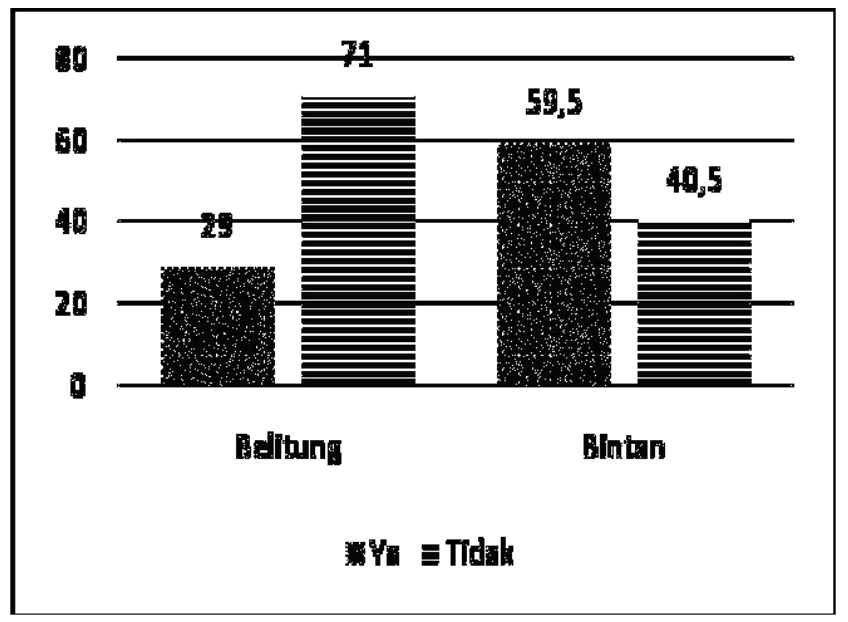

Grafik 3.

Pengalaman Menghadapi kekeringan dalam 10 Tahun Terakhir $(\%, \mathrm{n}=400)$
2014). Kejadian ini merupakan kekeringan terpanjang yang pernah dialami di Provinsi Kepulauan Riau. Sebelumnya, beberapa kasus kekeringan pernah terjadi yaitu pada tahun 1988/1989, 2005 dan 2011. Pada tahun 1988/1989 dan 2005 kekeringan yang melanda tidak separah pada tahun 2011. Tahun 2011, hujan juga tidak turun selama 30 hari (pada Bulan JanuariFebruari 2011). Di Bangka Belitung, walau kejadiannya belum pada level ekstrem seperti kejadian di Kepulauan Riau, namun hampir setiap tahun mengalami kekeringan yang biasanya terjadi pada Bulan Agustus, dan dari tahun ke tahun kejadian kekeringan semakin lama.

Dari pengalaman responden terhadap kejadian kekeringan dalam survei menunjukkan pola yang berbeda. Di Belitung, dalam sepuluh tahun terakhir, sebagian besar mengaku tidak mengalami kekeringan (71 persen). Sebaliknya di Bintan, hampir 60 persen rumah tangga mengalami kekeringan. Informasi yang lebih detil dapat dilihat pada grafik 3 berikut.

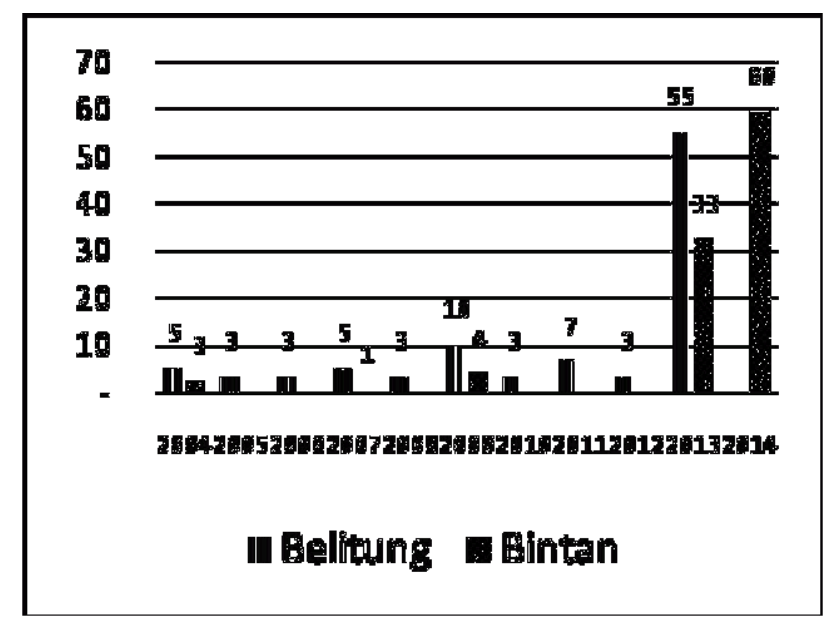

Grafik 4.

Tahun Kejadian Kekeringan dalam 10 Tahun Terakhir $(\%, \mathrm{n}=400)$

Sumber: Survei Pengarusutamaan Adaptasi dalam Peningkatan Resiliensi Pulau-pulau Kecil, Kerjasama PPK LIPI dan Geotek LIPI 2014

Pada grafik 4. Diatas terlihat bahwa 29 persen responden di Belitung mengalami kekeringan hampir setiap tahun dalam sepuluh tahun terakhir pada Bulan Agustus. Kejadian kekeringan yang paling parah dialami pada tahun 2013 $3^{14}$. Pada Bulan Agustus tercatat curah hujan memang selalu lebih sedikit dari bulan-bulan lainnya. Selain itu jumlah hari hujan juga lebih sedikit dibandingkan bulan lainnya. Kondisi ini

${ }^{14}$ Untuk tahun 2014, responden belum mengaku mengalami kekeringan karena survei dilakukan pada Bulan Juni 2014. 
sudah sering terjadi sehingga tidak heran masyarakat mengakui hampir setiap tahun mereka mengalami kekeringan pada Bulan Agustus. Namun intensitas kekeringan yang dialami di Belitung tidak separah yang terjadi di Bintan.

Di Kepulauan Riau, pada beberapa tahun menunjukkan terjadinya anomali cuaca yaitu pada tahun 1988/1989, 2005, 2011 dan 2014 $4^{15}$. Menurut Kepala Stasiun Meteorologi Kota Tanjung Pinang kejadian kekeringan tahun 2014 merupakan kejadian yang paling parah dialami di Kepulauan Riau dan hampir ditemui di semua wilayah provinsi ini kecuali wilayah Natuna dan Lingga ${ }^{16}$. Namun, dari hasil wawancara mendalam dan survei pada penduduk yang tinggal di Desa Mantang dan Desa Air Glubi, mereka mengaku kejadian kekeringan sudah dimulai pada Bulan Desember 2013 sampai awal Maret 2014. Hal ini terlihat dari hasil survei pada grafik 4 diatas.

\section{ADAPTASI YANG DILAKUKAN UNTUK PEMENUHAN KEBUTUHAN AIR BERSIH}

Secara umum masyarakat telah melakukan adaptasi untuk memenuhi kebutuhan air bersih. Sedangkan dari sisi pemerintah, kejadian kekeringan di Kepulauan Riau beberapa waktu yang lalu belum menjadi pertimbangan untuk melakukan adaptasi yang terencana (planned) sebagai upaya untuk mengantisipasi kondisi di masa mendatang dengan probabilitas kekeringan yang makin tinggi.

Untuk masyarakat, beberapa kegiatan adaptasi untuk pemenuhan kebutuhan MCK dan pemenuhan kebutuhan air minum merupakan kegiatan yang hampir sama seperti memperdalam sumur, mengambil air dari tempat/pulau lain dan membeli. Untuk kebutuhan MCK terdapat 2 persen responden yang membuat penampungan air untuk MCK. Sedangkan untuk pemenuhan kebutuhan airminum 20 persen responden di Belitung memilih untuk membuat sumur baru dan 9 persen lainnya melakukan upaya kombinasi mengambil di tempat lain dan membeli.

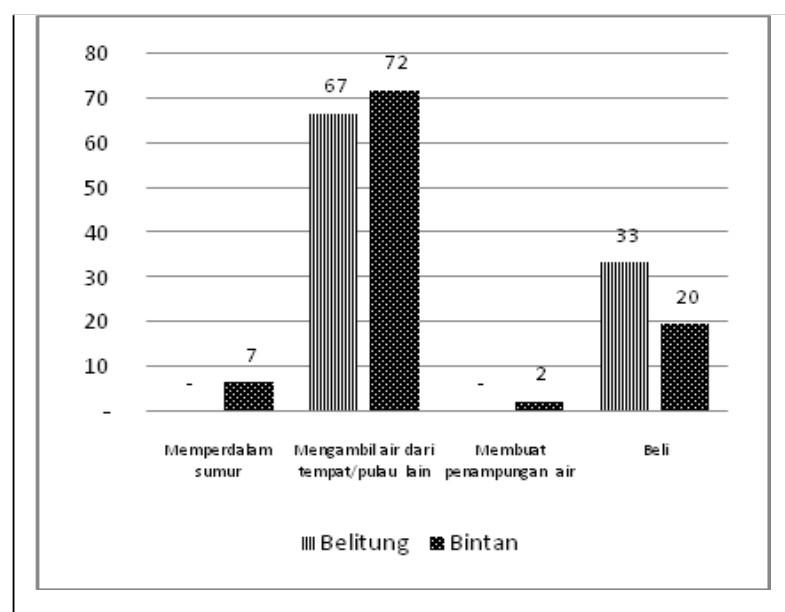

Grafik 5.

Response untuk Pemenuhan Kebutuhan MCK

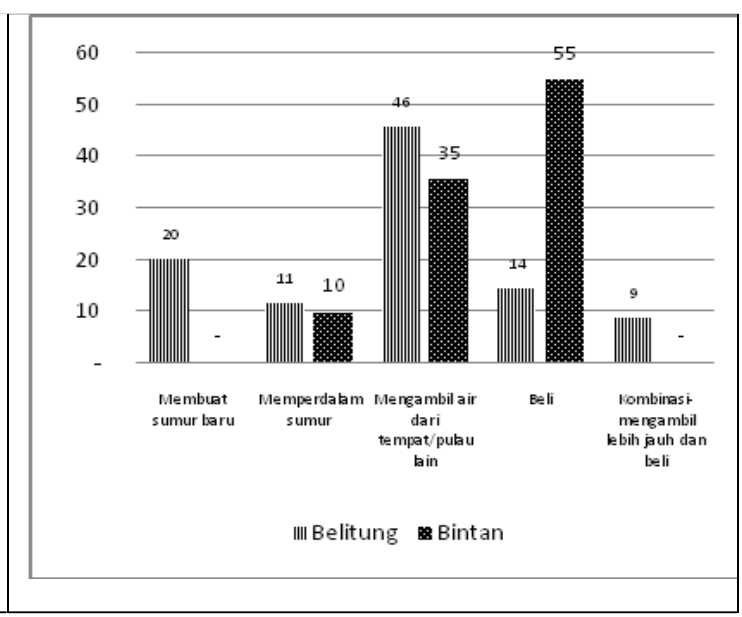

Grafik 6

Response untuk Pemenuhan Air Minum

Sumber: Survei Pengarusutamaan Adaptasi dalam Peningkatan Resiliensi Pulau-pulau Kecil, Kerjasama PPK LIPI dan Geotek LIPI 2014

\footnotetext{
${ }^{15}$ Pernyataan Kepala Stasiun Meteorologi Kota Tanjung Pinang yang dimuat di Batam Pos tanggal 4 maret 2014, diakses online tanggal 10 november 2014.

${ }^{16}$ Kedua wilayah mengalami hujan lokal pada pertengahan Bulan Februari.
} 
Secara lebih detil, berikut beberapa kegiatan adaptasi yang telah dilakukan penduduk di Bintan dan Belitung

\section{a. Mengambil air dari sumber air lain/ pulau lain}

Sebagai response yang paling mudah untuk mengatasi kesulitan air adalah dengan mengambil air dari tempat lain atau bahkan di pulau lain. Metode adaptasi seperti ini juga dapat ditemui di pulau-pulau kecil lain seperti di Kepulauan Spermonde. Hal ini dapat dilakukan di kawasan pulau-pulau kecil di Indonesia, karena seperti kasus di negara-negara Kepulauan Pasifik, air masih dikelola sebagai sumber daya yang bersifat common pool resource, yang didefinisikan sebagai sumber daya yang memiliki karakteristik ketidakjelasan sistem kepemilikan (property rights) dan tanggungjawab untuk menjaga kelestariannya (White, 2007). Demikian pula untuk wilayah Belitung dan Bintan.

Untuk Belitung maupun Bintan, penduduk yang mengalami kesulitan air bersih dapat pergi ke pulau lain atau ke sumber air lain di pulaunya (sumur/ kolam bersama) untuk mengambil air sesuai kebutuhan tanpa harus membayar kompensasi pengambilan air. Air dapat diambil oleh masing-masing keluarga sekuat mereka mengambil, karena biasanya harus diangkut jerigen/ ember dengan dipanggul atau dibawa dengan perahu. Terkadang hanya membutuhkan untuk mengantri apabila terjadi kekeringan.

Mayoritas responden di kedua lokasi penelitian harus mengambil air dari sumber lain/pulau lain untuk memenuhi kebutuhan air baik untuk keperluan MCK maupun air minum. Namun persentase yang melakukan respons ini lebih besar untuk keperluan MCK, yaitu sebesar 67 persen di Belitung dan 72 persen di Bintan. Untuk keperluan air minum, persentasenya tidak sebesar untuk pemenuhan kebutuhan MCK, hal ini disebabkan karena mayoritas respon yang ada di Bintan membeli air (55 persen).

Untuk Desa Air Glubi dan Desa Mantang juga ditemukan kasus yang mengambil air dari pulau lain dengan menggunakan sampan berdayung. Untuk mengambil air di pulau lain tidak diperlukan biaya karena pulau yang memiliki sumber air tawar berada relatif dekat dengan pulau tempat tinggal mereka. Pulau tempat mengambil air biasanya adalah pulau tidak berpenghuni sehingga debit air yang tersedia di sumur tersebut masih dapat mencukupi jika penduduk lain datang mengambil air. Terkadang dalam satu keluarga dilakukan pembagian tugas untuk mengambil air. Saat suami sedang melaut, para istri yang akan mengambil air. Namun bila suami sedang tidak melaut, biasanya para laki-laki yang mengambil air.

\section{b. Membeli}

Upaya yang juga banyak dilakukan oleh penduduk adalah membeli air. Secara umum air galon adalah air yang biasa dikonsumsi dengan membeli. Baik air galon yang bermerek maupun air isi ulang, alasan mengkonsumsi air galon lebih pada kepraktisan karena tidak perlu memasaknya. Namun disisi lain jumlah rupiah yang harus dikeluarkan juga tidak sedikit. Selain itu, kondisi pulau-pulau kecil membuat adanya tambahan biaya tansport untuk mengangkut air galon dari pulau besar ke pulau kecil. Dari hasil penelitian lapangan, di Kecamatan Selat Nasik (Pulau Mendanau) terdapat satu depot air isi ulang, yang mengambil air baku dari sumur yang ada di belakang depot air ini. Secara higienes tidak terlalu jelas kualitas dari produksi air ini, namun secara kuantitas produksi air isi ulang ini dapat membantu masyarakat.

Membeli air disini bukan hanya berarti membeli air galon untuk konsumsi air minum. Namun juga membayar orang lain sebagai jasa untuk mengangkut air sampai ke rumah. Biasanya air yang diangkut seperti ini selain dipergunakan untuk keperluan MCK juga untuk keperluan air minum. Sebagai contoh di Desa Air Glubi. Saat musim kering, biasanya penduduk akan meminta bantuan dari aparat desa yang biasa megoperasikan motor angkut untuk mengambilkan air di kolam bekas tambang yang terletak di tengah pulau. Biasanya mereka akan mengganti ongkos bensin secara sukarela.

\section{c. Menambah daya tampung sumber air yang sudah ada}

Pada tingkat masyarakat respon ini terkait dengan upaya untuk menambah stok air di sumber air yang sudah dipakai yaitu dengan jalan memperdalam sumur. Seperti yang dilakukan oleh sekitar 10 persen responden untuk memenuhi kebutuhan air minum baik di Bintan maupun di Belitung. Sedangkan untuk kebutuhan MCK hanya 7 persen responden di Bintan 
yang melakukan. Walaupun dilakukan, opsi ini bukan opsi yang populer. Di beberapa kasus, terkadang memperdalam sumur tidak mendapatkan hasil yang diharapkan.

Untuk kasus Pulau Seliu, terdapat satu sumber air utama di pulau tersebut yang dengan bantuan pemerintah diperdalam dan diperbesar kapasitas tampungnya. Pelaksanaan kegiatan (pada tahun 2014) masih belum selesai, beberapa agenda yang direncanakan adalah mendistribusikan air langsung ke rumah penduduk dan membangun sistem pengelolaan distribusi air.

Untuk tingkat kabupaten-di wilayah perkotaan, opsi ini pernah dilakukan oleh PDAM Tirta Kepri, Tanjung Pinang. PDAM menyebutkan bahwa pada tahun 2011, Waduk Sungai Pulai diperluas dengan menambah luas dan kedalaman waduk. Hal ini merupakan strategi jangka pendek untuk menambah stok air baku. Namun hal ini tidak dapat dilakukan di PDAM Tanjung Pandan Belitung karena pengerukan waduk akan berdampak pada menurunnya kualitas air karena tanah di sekitar kolong yang mengandung timah. Direktur PDAM Tanjung Pandan menyebutkan bahwa hal ini merupakan dilema untuk PDAM. Upaya untuk menambah persediaan air baku tidak memungkin dengan menambah kapasitas kolong. Yang mungkin dilakukan hanya mencari sumber air baku baru.

\section{d. Mencari sumber air baru}

Pada tingkat masyarakat upaya untuk mencari sumber air baru dilakukan dengan membuat sumur sebagai sumber air minum. Hal ini terlihat dari hasil survei (grafik 5.7), 20 persen dari responden membuat sumur baru di Belitung. Namun untuk pemenuhan kebutuhan air untuk MCK, respon seperti ini tidak dilakukan.

Pada sisi pemerintah, seperti di Bintan dilakukan upaya untuk mencari sumber air baru untuk sumber air baku PDAM di wilayah perkotaan. Selain membuat waduk baru (Waduk Sei Gesek), pemerintah Kabupaten Bintan juga mencari sumber air bawah tanah dengan membuat sumur bor sebanyak 5 buah pada tahun 2012. Namun hasil air yang diharapkan tidak didapat. Air yang keluar keruh dan hitam sehingga tidak layak untuk konsumsi air minum. Setelah dikuras selama beberapa bulan, dua sumur yang menghasilkan air cukup bening namun debit yang dihasilkan sangat kecil sehingga membutuhkan biaya yang sangat besar untuk mengoperasionalkannya. Untuk Belitung, PDAM juga mencoba untuk mencari sumber air baku yang berasal dari mata air di Batu Mentas. Namun hal ini belum dapat terealisasi, masih dalam taraf studi.

\section{e. Mempermudah distribusi air}

Kesulitan pemenuhan air yang terjadi di Desa Air Glubi diatasi dengan cara mengambil air di kolam eks tambang yang terletak di tengah pulau. Dengan kondisi pulau yang kecil dan permukiman masyarakat yang ada di pinggir pulau, maka mereka mengalami kesulitan transportasi untuk mengangkut air. Oleh karenanya, Pemerintah Desa Air Glubi mencoba mengusahakan angkutan untuk mengambil air dan mendistribuskannya ke rumah penduduk. Motor ini dilengkapi dengan bak penampung dan mesin diesel untuk menyedot/mendistribusikan air. Biasanya penduduk yang membutuhkan air akan mengontak operator motor ini untuk diambilkan air. Sebagai penggantinya, mereka membayar uang pengganti bahan bakar.

Untuk mengatasi kesulitan air, telah dicoba untuk membuat sumber-sumber air baru diantaranya difasilitasi oleh PNPM (di Belitung PNPM Pisew dan PNPM perdesaan di Bintan). Dari hasil wawancara mendalam dengan beberapa narasumber dan hasil observasi di lokasi sumber air ditemukan dua sistem distribusi air yang berjalan baik di dua lokasi yang berbeda.

Di Desa Mantang Riau-Bintan, PNPM merevitalisasi sumber air yang biasanya dimanfaatkan. Kolam eks galian tambang ini diperlebar dan diperdalam sehingga memiliki daya tampung yang lebih besar untuk keperluan penduduk desa. Selain itu, PNPM juga menfasilitasi distribusi air ke rumah-rumah penduduk dengan melengkapi sistem distribusi dengan pompa air, tandon air, pipa dan meteran untuk sampai ke rumah-rumah penduduk. Sistem ini seperti sistem yang berlaku di PDAM. Untuk itu setiap rumah tangga yang berlangganan diwajubkan untuk membayar sesuai dengan pemakaian. Selain itu sebagai pelanggan mereka juga harus membayar jasa pelanggan (abonemen). Untuk mengatur sistem ini, ditunjuk 
seorang koordinatordalam kasus Desa Mantang seorang tokoh masyarakat yang disegani merupakan koordinator yang dipilih. Sistem dibangun cukup transparan sehingga masyarakat dapat memantau pemasukan dan pengeluaran uang yang dibayarkan. Bahkan dalam beberapa bulan terakhir biaya pemakaian air per kubik turun dari Rp. 6.000 menjadiRp. 5.000 Hal ini tentu saja meringankan beban masyarakat untuk pengeluaran air. Dari uang hasil pembayaran pelanggan telah dapat dimanfaatkan untuk menambah tandon air.

Sistem yang berbeda dapat ditemui di Desa Suak GualSelat Nasik, PNPM juga menfasilitasi pembuatan sumur sampai distribusi air ke rumah-rumah. Pada awalnya, pengeluaran untuk listrik dibebankan pada para pemakai sumber air tersebut dengan sistem pembayaran secara sukarela. Sistem ini juga dilakukan termasuk untuk biaya servis pompa atau pembeliaan pompa baru saat pipanya rusak.

\section{f. Desalinisasi air}

Di beberapa lokasi ditemukan alat untuk desalinisasi air, yang biasanya merupakan projek langsung lewat APBN. Alat untuk desalinisasi dengan skala besar berada di Kota Tanjung Pinang, namun sampai saat ini- alat yang sudah dipasang sejak tahun lalu belum dimanfaatkan karena permasalahan teknis aliran listrik yang dibutuhkan untuk mengoperasikan alat tersebut dan masalah mekanisme pengaturan operasionalnya. Begitu juga untuk alat desalinisasi dengan kapasitas kecil yang ada di Desa Mantang, belum secara resmi beroperasi.

\section{g. Pemanenan air hujan (tradisional)}

Pemanenan air hujan belum banyak dilakukan di Bintan maupun Belitung. Dari observasi lapangan, hanya sedikit rumah tangga yang melakukan upaya untuk memanen air hujan langsung dari atap. Sebagai contoh beberapa rumah tangga di Pulau Rengit Belitung, memanen air hujan dengan langsung mengalirkan air dari atap, dengan melakukan penyaringan sebelum masuk ke dalam tong-tong plastik. Biasanya air hujan dipakai sebagai sumber air minum karena air sumur di rumah ini merah.

\section{h. Menjaga ekosistem hutan mangrove di Selat Nasik}

Penduduk yang tinggal di Kecamatan Selat Nasik dengan pulau Mendanau sebagai sentra permukiman masyarakat, telah mencoba membuat kesepakatan untuk selalu tetap menjaga kelestarian lingkungan pulau tersebut. Terkait dengan air, beberapa inisiatif lokal yang signifikan adalah adanya (1) upaya untuk menjaga kawasan hutan di sekitar Lembong Dalam. Daerah ini merupakan sumber air bersih untuk penduduk di Desa Ptaling, bahkan apabila musim kering, sumber air ini menjadi sumber air untuk dua desa lainnya. (2) Menjaga Mangrove yang ada di sekeliling Pulau Mendanau. Mangrove yang ada cukup lebat sebagai penahan angin dan ombak besar. Selain itu juga menjaga keberadaan sumber air. Kesadaran penduduk akan pentingnya menjaga kelestarian lingkungan bagi kehidupan mereka terlihat pula dari upaya untuk menghentikan penambangan di Selat Nasik pada tahun 2008. Pada saat itu, bupati memberikan ijin penambangan pada swasta. Namun masyarakat menolak mengingat ekosistem pulau yang sangat terbatas.

\section{MEMAHAMI ADAPTASI PEMENUHAN KEBUTUHAN AIR BERSIH DI PULAU KECIL}

Dengan mempergunakan kuadran yang dikembangkan oleh Tompkins dkk (2008), terlihat persebaran kegiatan adaptasi yang telah dilakukan yakni secara reaktif masyarakat lebih menitikberatkan pada kegiatan yang dianggap bisa membantu dalam jangka pendek yaitu membeli (air minum) dan mengambil dari sumber lain/ pulau lain. Terkadang juga mengupah untuk mengambilkan air dari sumber lain/pulau lain. Dari sisi pemerintah, kegiatan adaptasi yang bersifat reaktif didominasi dengan upaya untuk menambah stok air dengan memperdalam/ memperluas sumber air.

Untuk adaptasi yang bersifat antisipatif juga masih didominasi dengan kegiatan yang bersifat fisik untuk meningkatkan pasokan air bersih, baik dari sisi pemerintah maupun lokal. Mencari sumber air baru menjadi salah satu kegiatan adaptasi yang paling populer. Namun demikian, kondisi ini akan menjadi sulit untuk kasus pulau kecil, karea keterbatasan kondisi pulau-pulau kecil. Selain itu, untuk kasus 
Belitung, tidak semua sumur baru yang dibuat dapat menghasilkan air dengan kualitas baik. Kebanyakan air yang ada di sumur-sumur di Belitung adalah air yang berwarna kemerahan (ai teraja').

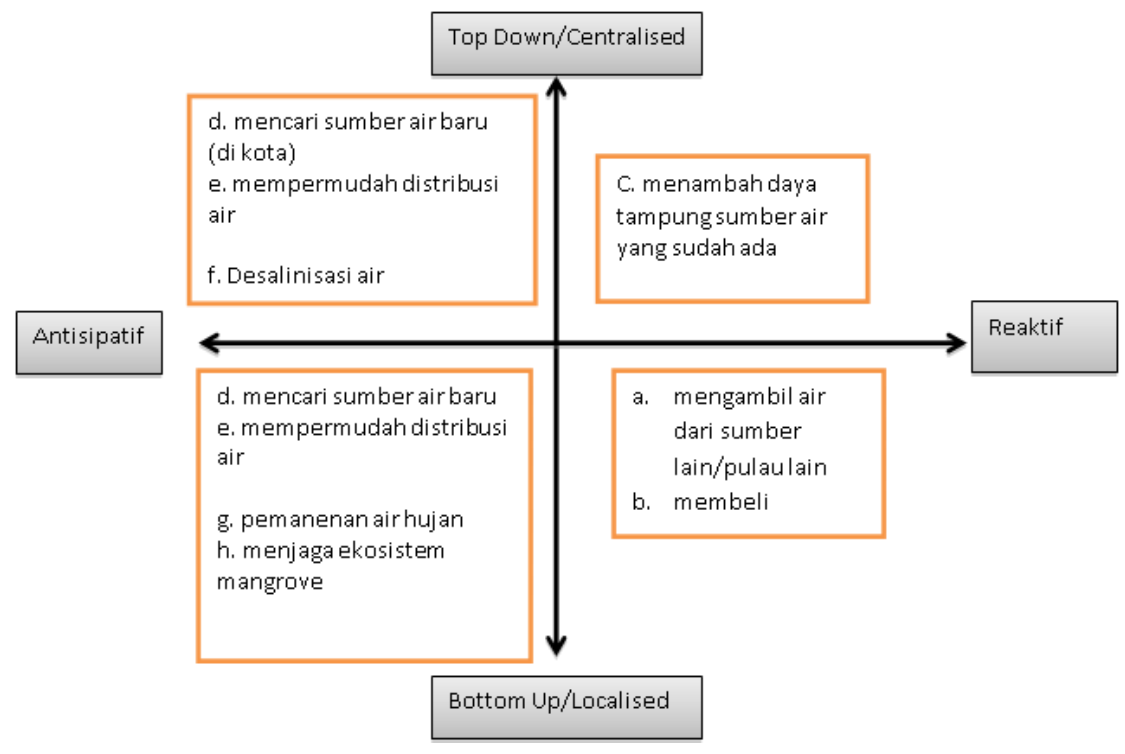

Gambar 4.

Pemetaan Kegiatan Adaptasi di Bintan dan Belitung dengan Empat Kuadran Tompkins

Kegiatan yang bersifat fisik lainnya yang dilakukan adalah dengan melakukan desalinisasi air laut yang dilakukan oleh pemerintah. Pembangunan peralatan untuk desalinasi air merupakan investasi yang cukup mahal. Selama ini, kebanyakan pembangunan peralatan ini mempergunakan dana APBN yang berasal dari Kementerian Kelautan dan Perikanan (KKP). Beberapa kasus di pulau-pulau kecil yang ada di Sulawesi dan Kalimantan, peralatan untuk desalinisasi tidak dapat bertahan lama, karena kurangnya sistem perawatan dan sistem transfer teknologi pada pengelola lokal (Rachmawati dan Purwaningsih, 2014). Desalinisasi air memang merupakan alternatif masa depan untuk memenuhi kebutuhan air bersih penduduk, namun demikian perlu untuk dipikirkan transfer teknologi yang efektif dan murah bagi masyarakat lokal sehingga alternatif pemanfaatan teknologi ini dapat tetap berlanjut dan lestari.

Pada tingkat masyarakat, ditemui beberapa rumah tangga yang melakukan pemanenan air hujan (Rain water harvesting). Kegiatan ini lebih dilakukan secara individual oleh rumah tangga yang memiliki sumur dengan air merah. Belum ada upaya untuk mengangkat kegiatan ini pada tingkat yang lebih luas. Padahal, kegiatan pemanenan air hujan merupakan salah satu kegiatan adaptasi yang banyak direkomendasikan di berbagai tempat untuk mengatasi permasalahan air (UNEP, 2009; Boelee, 2013). Di beberapa tempat kegiatan pemanenan air hujan dilakukan pada tingkat komunal sehingga bak penampung yang dipergunakan dalam skala besar dan rumah tangga-rumah tangga yang tinggal di sekitar sumber air dapat memanfaatkannya. Pemanenan air hujan memiliki potensi yang cukup besar dikembangkan untuk masa mendatang. Namun modifikasi teknologi termasuk untuk tempat penyimpanan air menjadi penting, mengingat perubahan temperatur dan curah hujan yang makin terasa di masa datang.

Khusus di Selat Nasik, terdapat kawasan mangrove yang masih lebat dan terjaga. Terdapat aturan lokal yang disepakati bersama untuk menjaga kelestarian hutan mangrove yang ada. Secara ekologis, mangrove dapat berperan untuk menjaga intrusi air laut, selain itu juga sebagai penahan gelombang atau badai. Terkait dengan perubahan iklim, mangrove memiliki peran 
ganda untuk kepentingan mitigasi dan adaptasi sekaligus. Untuk mitigasi, mangrove mampu untuk mengurangi emisi karbon. Sedangkan untuk adaptasi, mangrove berperan penting untuk menjaga air bersih dari intrusi air laut. Peran masyarakat lokal dalam menjaga ekosistem mangrove secara langsung berdampak pada keberlangsungan pasokan air bersih untuk penduduk di Pulau Mendanau, Selat Nasik. Walaupun kondisi kekeringan, mereka masih memiliki sumber air yang dapat dimanfaatkan untuk kepentingan penduduk Selat Nasik.

Distribusi air menjadi satu hal penting yang tidak dapat dilepaskan dari pengelolaan air (water governance). Menurut Tompkins dan Adger (2004) water governance mengampil peran yang krusial untuk mewujudkan efektif adaptasi. Dalam bukunya Hill ( 2013) menyebutkan bahwa dalam konteks perubahan iklim dimana terjadi perubahan secara biofisik, water governance menjadi esensial karena mengatur variabilitas pasokan air, distribusi, pengaturan infrastruktur, aturan-aturan dan berperan sebagai administrator dari sistem yang dibangun ini. Pengaturan seperti yang dilakukan di Mantang merupakan salah satu contoh dari pengelolaan air yang bersifat lokal untuk memenuhi kebutuhan lokal. Pembentukan badan pengelola yang secara profesional mengatur masalah teknis dan administrasi menjamin distribusi air yang adil untuk semua penduduk yang ada di Dusun Mantang Riau. Peran kepemimpinan dan sistem pengelolaan yang bersifat adaptif menjadi input yang memperkuat sistem pengeloaan air yang dibangun.

Di sisi lain, sistem pengaturan air di sumur lama Desa Suak Gual, mungkin menjadi model pengelolaan air yang paling sederhana. Namun demikian, sistem ini menjadi rentan apabila ada pengambil air yang tidak menuruti aturan main yang berlaku karena aturan tersebut tidak tertulis dan tanpa adanya badan pengelola dan pengawas pemanfaatan sumber air. Penentuan tarif lebih diutamakan untuk menutup biaya operasional seperti untuk listrik pompa air maupun biaya administrasi pengurus. Namun kesadaran bahwa pengelolaan air adalah untuk kepentingan bersama maka biaya ditekan seminimal mungkin agar masyarakat tidak merasa berat untuk membayarnya.

\section{KESIMPULAN}

Adaptasi pemenuhan kebutuhan air bersih di pulaupulau kecil yang diteliti masih menitikberatkan pada adaptasi responsif/reaktif. Adaptasi yang bersifat antisipatif telah mulai menjadi perhatian, namun masih banyak hal yang perlu dipertimbangkan terkait dengan kondisi fisik pulau-pulau kecil seperti teknologi yang lebih efektif untuk penduduk pulau-pulau kecil maupun pembiayaan yang sesuai dengan kondisi pulau kecil. Upaya menghubungkan pasokan air bersih dengan ekosistem, dalam hal ini mangrove, adalah satu hal penting mengingat peran mangrove untuk menahan intrusi air laut dan menahan gelombang atau badai. Peran penjaga dari mangrove tidak hanya secara fisik namun juga untuk keberlangsungan sumber air.

Selain itu untuk memahami pemenuhan kebutuhan air bersih di pulau-pulau kecil tidak hanya melihat kondisi fisik dari sumber daya air yang dimanfaatkan, namun pengelolaan air (water governance) untuk kepentingan penduduk pulau-pulau kecil harus menjadi perhatian utama mengingat kondisi pulau-pulau kecil yang akan makin rentan dengan adanya perubahan iklim. Pengelolaan air yang adaptif merupakan salah satu upaya untuk meningkatkan kapasitas adaptasi penduduk terhadap perubahan iklim yang dapat mengurangi kerentanan penduduk terhadap pemenuhan kebutuhan air di pulau-pulau kecil.

\section{DAFTAR PUSTAKA}

Adger, Neil W. Dkk. 2003. "Adaptation to Climate Change in the Developing World". Progress in Development Studies. 3,3 pp179-195

Bergkamp, Ger. Orlando, Brett dan Burton, Ian. 2003. Change. Adaptation of Water Management to Climate Change. IUCN, Gland, Switzerland and Cambridge, UK

Boelee, Eline dkk. 2013. "Options for water storage and rainwater harvesting to improvehealth and resilience against climate change in Africa" Regional Environmental Change 13: 509-519

Falkland, Anthony C. 1992.Small Tropical Islands: Water Resources of Paradise Lost. International Hydrological Programme and Man and Biosphere Programme - UNESCO 
Falkland, Anthony C. 1993.Hydrology and water management on small tropical islands. Hydrology od Warm Humid Region. Proceedings of the Yokohama Symposium July 1993. IAHS Publ. No 216.

Hill, Margot. 2013. Climate Change and Water Governance: Adaptive Capacity in Chile and Switzerland. Springer

Kementerian Lingkungan Hidup(KLH), GTZ, WWF. 2010. Kajian Risiko dan Adaptasi Terhadap Perubahan Iklim Pulau Lombok, Provinsi Nusa Tenggara Barat. Sektor Sumber Daya Air. Jakarta:Kementerian Lingkungan Hidup.

Kuruppu, Natasha. 2009.“Adapting water resources to climate change in Kiribati: the importance of cultural values and meanings". Environmental Science and Policy 12:799-809.

Nurse, Leonard A. dkk. 2014. "Small Island". dalam Climate Change 2014: Impacts, Adaptation and Vulnerability. Part B: Regional Aspects Contribution of Working Group II to the Fifth Assessment Report of the Intergovernmental Panel on Climate Change (Barros, VR dkk) Cambridge University Press. Pp $1613-1654$

Rachmawati, L dan Purwaningsih, SS. 2014. "Indikator Sosial untuk Memahami Pengarusutamaan Adaptasi untuk Peningkatan Resiliensi Pulau-pulau Kecil" dalam Heru Santoso (ed) Membangun Strategi Adaptasi Perubahn Iklim. Pusat Penelitian Geoteknologi LIPI

Scherdtner Manez, Kathleen dkk. 2012."Water Scarcity in the Spermonde Archipelago, Sulawesi, Indonesia: Past, Present and Future".Environmental Science and Policy 23: 74-84.
Tompkins EL. dkk. 2005. Surviving Climate Change in Small Islands- a guidebook, UK: Tyndall Centre for Climate Change Research,.

Tompkins EL, Adger WN. 2004. "Does adaptive management of natural resources enhance resilience to climate change?"EcolSoc 9(2):10

Tompkins E.L; Few, Roger dan Brown, Katrina. 2008. "Scenario-based stakeholder engagement: Incorporating stakeholders preferences into coastal planning for climate change". Journal of Environmental Management 88: 1580-1592.

UNEP dan SEI. 2009. Rainwater Harvesting: A lifeline for human well-being. A report prepared for UNEP by Stockholm Environment Institute.

White, Ian dkk. 2004.Sustainable Development of Water Resources in Small Island Nations of The Pacific, Proceedings of the 2nd Asia Pacific association of hydrology and water resources Conference, Singapore, 5-8 July 2004. s.1. : s.n., pp. 345-356.

White, Ian dkk. 2007."Challenges in freshwater management in low coral atolls". Journal of Cleaner Production 15:1522-1528.

White, Ian dan Falkland, A.C. 2010. "Management of Freshwater Lenses on Small Pacific Islands" Hydrogeology Journal. 18:227-246. 
Jurnal Kependudukan Indonesia | Vol. 10, No. 2, Desember 2015 | 109-124 